\title{
WILL THE WINNER STILL BE THE WINNER? A STUDY OF EQUITY MUTUAL FUND PERFORMANCE IN INDONESIA
}

\author{
Budi FRENSIDY (1) ${ }^{*}$, Reynardo NAINGGOLAN (D)2, Robiyanto ROBIYANTO (1)3 \\ ${ }^{1,2}$ Faculty of Economics and Business, Universitas Indonesia, Depok 16424, West Java, Indonesia \\ ${ }^{3}$ Faculty of Economics and Business, Satya Wacana Christian University, Salatiga 50711, Central Java, Indonesia
}

Received 18 November 2019; accepted 09 March 2020

\begin{abstract}
In this study, we explore the consistency of Indonesian Rupiah (IDR) - denominated equity mutual funds offered in Indonesia from 2007 to 2017 from various holding periods, namely one year, three years, and five years. Two questions are addressed. Will the winning mutual funds be the winner in the following period? Is the performance of a longer period more persistent than that of the shorter period? Using the nominal return from these eleven years, we find that the equity mutual funds in Indonesia earn no stable performance. The winner will not always be the winner in the following observed period. In addition, no evidence is found that long-term performance would result in a better persistence than that of the shorter time frame.
\end{abstract}

Keywords: equity mutual fund, performance consistency, Indonesia.

JEL Classification: G10, G11.

\section{Introduction}

The preference to invest in equity mutual fund (later will be stated as equity fund) in Indonesia is increasing. Based on data from Indonesia Financial Services Authority (OJK), the asset under management (AUM) of Rupiah (IDR)-denominated equity funds offered in Indonesia has grown $242.1 \%$ from IDR37.7 trillion in year-end 2007 to IDR128.9 trillion in year-end 2017. At the same time, the number of equity funds has increased by $291.2 \%$ from 57 funds in 2007 to 223 funds in 2017.

Investors can allocate money in stocks either directly by investing in the stock market or indirectly by buying equity funds. Investing in individual stocks will be exposed to unsystematic risk. To eliminate this, investors need to diversify their portfolios (Frensidy et al., 2017). As an alternative, individual investors can choose to invest in equity fund, not directly in stock market, because the fund manager is considered better trained on timing and stock selection (Angelidis et al., 2013; Frensidy, 2016; Glode, 2011; Grau-Carles et al., 2018; Rao et al., 2017; Robiyanto et al., 2019; Turtle \& Zhang, 2012). The prevailing regulation regarding equity fund says the proportion of stocks in each equity fund should be at least $80 \%$ (the other proportion could be cash or money market instruments). Therefore, both direct and indirect investing eventually have a similar fundamental exposure, namely volatility of the stock market (systematic risk).

Based on risk-return trade-off, investors would prefer to invest in an asset class as long as the return is higher than the risk. In this case, predictability of the future return is really important to manage the expected cash flows. Investors could use the historical performance of the equity fund to predict what will happen in the future. Therefore, to get a better result, investors should put their funds in equity funds on the long-term horizon (more than one year). However, in response to the higher return, the risk of holding in a long time also increases. In general, for individual investors (mostly unsophisticated ones in Indonesia), this condition could be uncomfortable or even deceitful. No reliable and recent scientific study has addressed this issue about the reliability of historical fund performance.

Some studies have tried to investigate the persistence of more than one type of mutual fund performance i.e. Antonakakis et al. (2018), Grau-Carles et al. (2018), Matallín-Sáez et al. (2019), Shive and Yun (2013), VidalGarcía et al. (2016), Wattanatorn et al. (2020). However, the shortcomings of the previous researches are they use sample (not population), the population or sample data is not long enough (for example, it was only two years),

${ }^{*}$ Corresponding author. E-mail: budi.frensidy@ui.ac.id 
and the data was not analyzed from different time frames (for example, the time frame of performance was only one year).

Research on sampling will be exposed to sampling risk and it is subject to how the sample is taken. Different and extended time frames (one year, three years, and five years) could reduce the event error that may cause a certain time frame (for example, one year only). In other words, certain investors could only be short-term opportunists exploiting certain events (for example, the presidential election in Indonesia) that affects the volatility of certain stocks. Because of this, the persistence of short-term performance could be different from that of longer-term performance. Older data may have different conditions that cannot be compared to current findings. For example, research in the 1960s about the US mutual fund will be subject to a certain racial issue that is already solved in the US. About the period of data taken, the most recent research on mutual fund performance was in 2017, but it was based on the performance of the equity fund manager, not on that of an equity fund.

The goal of this study is to observe the performance persistence of the equity fund population (not only a sample) in various and long enough time frames (one, three, and five years) of the most recent equity funds (from 2007 to 2017). Any investors (both institutional and individual investors) would find this research helpful when allocating money in equity funds according to the investor's risk tolerance, goals, and investment time frame. For academic purposes, Deb (2019) says that it is an important step to test the efficient market hypothesis by assessing the existence and persistence of mutual funds.

Below is the hypothesis test that we employ to achieve the objective of the study:

$\mathrm{H}_{1}$ : There is the persistence of equity fund performance.

\section{Literature review}

Mutual fund performance is an interesting topic for both academicians and practitioners in the financial world. According to Deb (2019), importance occurs because of its significant effect on wealth. Some studies have been conducted regarding mutual fund performance. Babalos et al. (2015) studied the US equity mutual funds, and found the existence of size and return trade-off. Angelidis et al. (2013) develop an approach to measure mutual fund performance. This approach employs a factor exposure-based approach for measuring the - static and dynamic - timing capabilities of mutual fund managers. Angelidis et al. (2013) argue that market timing capabilities have a significant impact on excess return variance, while Dumitrescu and Gil-Bazo (2018), Fortin and Michelson (2010), VidalGarcía (2013) indicate that the performance of the mutual fund is persistent. Fortin and Michelson (2010) investigate the performance of all funds, comprising three groups of bond funds, equity funds, and one class of balanced funds, while Vidal-García (2013) investigates the performance of European equity mutual funds. This finding also supported by Filip (2018). While Fortin and Michelson (2010), Robiyanto et al. (2019) and Filip (2018) analyze the performance of all funds, Deb (2019), Pangestuti et al. (2017), Widodo and Robiyanto (2018) only test the performance of equity funds.

A different result is given by Fan and Addams (2012) who examine the market performance of US-based international mutual funds that invest only in the capital markets outside the US from 2005 to 2009 . They conclude that the relative performance of each fund develops more like a random walk than a stable and continuous trend. Fan and Addams (2012) examine data of the last twelve years of the US-based international mutual funds. We will examine this issue on the Indonesia-based equity fund.

Regarding equity funds in Indonesia, Pangestuti et al. (2017), Robiyanto et al. (2019), Widodo and Robiyanto (2018) discovers that the winner of Indonesian equity funds will be the winner in the next period. However, we find the shortcomings of Pangestuti et al. (2017), Widodo and Robiyanto (2018) as they only tested the consistency of equity funds for a one-year time frame. This short-term persistence is in line with some of the previous researches (Christiansen et al., 2020; Deb, 2019; Jeon et al., 2017; Rao et al., 2017; Vidal-García et al., 2016). On the contrary, Deb (2019) finds that among the best performing growth funds and the worst-performing small-cap funds show persistence in the long run-time period (Rodriguez \& Joseph McCarthy, 2015). In addition, Deb (2019) says that there is a consistency of performance, at least over funds with a short time horizon. The processes that they employ are first, they employ the four-factor model over a base quarter to rank mutual fund performance, second, they assign funds into one of the deciles according to the alpha of base-period, and third, they see the subsequent quarter performance. However, in this study, we do not classify the types of equity funds.

For the benefit of research on mutual funds to potential investors, Deb (2019), Nguyen et al. (2018), Rodriguez and Joseph McCarthy (2015) and Rao et al. (2017), VidalGarcía et al. (2016) suggest that investors should consider more than recent past performance before choosing from the available mutual funds. They should also consider other issues such as recent trends in the overall stock market and the investment policy stated in the prospectus of mutual funds. Ibbotson and Kaplan (2015) find that the investment policy explains about ninety percent of the inconsistency in returns of a typical fund across time. While Matallín-Sáez et al. (2016) find that the persistence of mutual fund performance depends on sub-periods used in the study.

Our study differs from previous studies in terms of the objects and time frames studied. When investigating equity fund performance, we explore the population of equity funds in Indonesia for the observed period (2007-2017). As mentioned earlier, different and extended time frames 
(one year, three years, and five years) could reduce the event error that may cause a certain time frame (for example, one year only). We feel that the last eleven years is long enough because the mutual fund industry just started in Indonesia in 1996. This is consistent with Christiansen et al. (2020) that say mutual fund performance requires a combination of data and judgment, and also consistent with Filip (2018) and Christiansen et al. (2020).

\section{Method}

The population of this research is all equity funds in Indonesia from the most recent data that are obtained from Otoritas Jasa Keuangan or the Indonesian Financial Service Authority $(\mathrm{OJK})$ and the Indonesia Stock Exchange (IDX). We see that the equity fund in Indonesia grows $242.1 \%$ from IDR37.68 trillion in 2007 to IDR128.9 trillion in 2017. At the same time, the number of funds increases $291.2 \%$ from 57 funds in 2007 to 223 funds in 2017. All equity funds with different attributes such as diverse sectors and different strategies (for example, passive or indexing and aggressive) are included.

Rao et al. (2017) observe some specific features of mutual funds and the effect of these on the general performance of the mutual fund. His research significantly contributes the present literature by presenting new evidence on the causal effects of certain mutual fund characteristics of a mutual fund on the total performance by using: (a) various time frames, (b) various features, and (c) more contemporary facts. Filip (2018) and Christiansen et al. (2020) did a relative similar study with Rao et al. (2017), but by using only short-term performance. Consistent with Rao et al. (2017), this research will consider two of these three categories, namely diverse periods and the most recent data. This research does not investigate the different attributes of equity funds.

We separate the gross return of equity funds based on the observation period, namely one year, three years, and five years. The definition of gross return is the increase/ decrease of the mutual funds' net book value (NBV) in the observed period, as stated below.

Gross return $=\left(\mathrm{NBV}_{\mathrm{t}=1}-\mathrm{NBV}_{\mathrm{t}=0}\right) / \mathrm{NBV}_{\mathrm{t}=0}$.

The definition of NBV in equity funds refers to the total value of assets minus its total liabilities divided by several outstanding units or shares. In addition, the gross return may still be subject to relevant fees and expenses that are not investigated in this research.

The test of persistence is carried out with the following steps. First, we include all equity funds that are offered during that relevant period. There was no survivorship bias here as all mutual funds offered in 2007 were included in the following period. Researches about the effect of survivorship bias on mutual fund performance are well documented in finance literature. Fortin and Michelson (2010) include a survivorship bias when researching the persistence of mutual fund, but Hanke et al. (2018) have found that none survivorship bias happened. Wattanatorn et al. (2020) notify that some fund managers frequently terminate their worst underperforming funds. Based on research on a sample free of survivorship bias, Nguyen et al. (2018) demonstrate that the predictability in equity funds' mean and risk adjusted-returns can be explained by common factors in stock returns and investment expenses. Nguyen et al. (2018) also add that stock selection skill cannot affect the consistency of mutual fund performance. This also supported by Rao et al. (2017) and Wattanatorn et al. (2020).

In this paper, all equity funds with both passive and active investing are incorporated. The fund manager is required to cover some costs in aggressive investing. Deb (2019) and Wattanatorn et al. (2020) finds that compared to a passively managed fund, the actively managed fund is more consistent with a world of rational and value-maximizing investors that compete with each other. However, according to Fama and French (2010), there is a constraint on the returns of active investing. One of the factors is the amount of transaction fee.

Second, we calculate the gross return of the observed period, namely one year, three years, and five years. The gross return is a representation of asset performance. In this paper, the risk-adjusted return is not used. In general, there are two types of risk-adjusted returns, which are related to total risk (Sharpe ratio) and systematic risk (Treynor ratio) (Devaney et al., 2016; Robiyanto et al., 2017; Zulkafli et al., 2017). Kourtis (2016) says that the Sharpe ratio is better to see equity fund performance. To identify superior performance, investors can use Alpha Jensen. In summary, stock selection and market timing are factors that affect the existence of alpha. To separate the impact of both stock picking and market timing on the alpha, Treynor (2012) modify Alpha Jensen to measure the market-timing capability.

Third, we calculate the median return of all equity funds in each period. Median return is used, instead of mean return, to reduce the effect of outliers, which might skew the mean of the gross return. The skewness is essential to be reduced. When skewness is combined with poor judgment, it can have adverse effects. For example, just before the 2008 crisis, positive skewness (the mean was higher than the median) existed in the equity market, and because of this, investors invested massively. Later, they exited the capital market after noticing the negative skewness in the market (the mean was lower than the median), investors sold at the bottom price.

Fourth, we group whether each equity fund is the winner (if the return is equal to or above the median return), or the loser (if the return is below the median). After that, we classify the winner and loser funds into 6 (six) clusters. They are (1) the winner in the current period that is the winner in the following period, (2) the winner in the current period that is the loser in the following period, (3) the winner in the current period that does not exist anymore in the following period, (4) the loser in the current period that is the winner in the following period, (5) the loser in 
the current period that is the loser in the following period, and (6) the loser in the current period that is not offered anymore in the market.

As an additional clarification, the equity fund could also be benchmarked against the relevant stock market indexes (such as Jakarta Composite Index (JCI) in the Indonesia Stock Exchange (IDX) or JKSE Index) or the top 45 most liquid stock traded in the IDX (LQ45)). We can further investigate this issue in the next research on whether the equity funds can outperform the relevant stock index.

Fifth, we test the consistency of the performance of each fund using the Chi-square test. In detail, we check if the winner will be the winner in the following relevant period and the loser will lose again in the next period. For example, the one-year return 2008 was compared to the one-year return of 2007, the three-year return of 2008 to 2010 was compared to the three-year return of 2005-2007, and the five-year return of 2008-2012 was compared to that of 2003-2007. For that purpose, we also gather the data of three-year return and a five-year return of all equity funds ended on 31 December 2007.

The formula for Chi-Square $\chi^{2}$ is stated below:

$$
\chi^{2}=\left[\Sigma(\mathrm{O}-\mathrm{E})^{2}\right] / \mathrm{E}
$$

where $\mathrm{O}$ symbolizes the observed frequency and $\mathrm{E}$ is the expected frequency. In this stage, we can observe the performance persistence of each time frame (one year, three years, and five years) from various periods.

\section{Result and discussion}

\subsection{Descriptive and Chi-Square result}

Table 1 displays the annual growth of the number of equity funds from the year 2007 to the year 2017. We can see that the number of equity funds offered increases significantly from year to year, except in 2010 and 2011.

Table 1 . The growth of equity funds (source: Infovesta, processed by the authors)

\begin{tabular}{|c|c|c|}
\hline Year & $\begin{array}{c}\text { Number of Equity } \\
\text { Funds Offered }\end{array}$ & $\begin{array}{c}\text { Annual Growth } \\
(\%)\end{array}$ \\
\hline 2017 & 223 & 22.5 \\
\hline 2016 & 182 & 25.5 \\
\hline 2015 & 145 & 16.9 \\
\hline 2014 & 124 & 30.5 \\
\hline 2013 & 95 & 23.4 \\
\hline 2012 & 77 & 18.5 \\
\hline 2011 & 65 & 3.2 \\
\hline 2010 & 63 & -7.4 \\
\hline 2009 & 68 & 25.9 \\
\hline 2008 & 54 & 54.3 \\
\hline 2007 & 35 & \\
\hline
\end{tabular}

Table 2 provides information about the median gross return of all equity funds in a particular period. We can see that the returns (both mean and median) of equity investing are uncertain. For example, the table shows that equity fund managers could make the big return of $55.9 \%$ (median) and $53.4 \%$ (mean) in 2007, but one year later in 2008 , they lost a huge amount of money of $52.9 \%$ (median) and $52.7 \%$ (mean).

Table 2. The mean and median of equity fund return and JKSE return (source: Infovesta and Yahoo Finance, processed by the authors)

\begin{tabular}{|c|c|c|c|}
\hline \multirow{2}{*}{ Period } & \multicolumn{2}{|c|}{ Equity Fund Return } & \multirow{2}{*}{$\begin{array}{c}\text { JKSE } \\
\text { Return (\%) }\end{array}$} \\
\hline & Median (\%) & Mean (\%) & \\
\hline \multicolumn{4}{|l|}{1 Year } \\
\hline Jan to Dec 2017 & 12.7 & 12.1 & 20.0 \\
\hline Jan to Dec 2016 & 10.9 & 9.1 & 15.3 \\
\hline Jan to Dec 2015 & -14.0 & -14.5 & -12.1 \\
\hline Jan to Dec 2014 & 27.4 & 25.8 & 22.3 \\
\hline Jan to Dec 2013 & -4.4 & -2.8 & -1.0 \\
\hline Jan to Dec 2012 & 9.7 & 9.9 & 12.9 \\
\hline Jan to Dec 2011 & -1.3 & -0.7 & 3.3 \\
\hline Jan to Dec 2010 & 33.4 & 33.8 & 46.0 \\
\hline Jan to Dec 2009 & 97.8 & 96.4 & 87.0 \\
\hline Jan to Dec 2008 & -52.9 & -52.7 & -50.6 \\
\hline Jan to Dec 2007 & 55.9 & 53.4 & 52.1 \\
\hline \multicolumn{4}{|l|}{3 Years } \\
\hline Jan 2015 to Dec 2017 & 7.3 & 3.8 & 21.6 \\
\hline Jan 2014 to Dec 2016 & 20.4 & 18.4 & 23.9 \\
\hline Jan 2013 to Dec 2015 & 3.4 & 5.5 & 6.4 \\
\hline Jan 2012 to Dec 2014 & 33.6 & 35.5 & 36.8 \\
\hline Jan 2011 to Dec 2013 & 7.5 & 8.8 & -13.5 \\
\hline Jan 2010 to Dec 2012 & 48.4 & 50.5 & 70.3 \\
\hline Jan 2009 to Dec 2011 & 168.1 & 173.4 & 182.0 \\
\hline Jan 2008 to Dec 2010 & 29.3 & 31.8 & 34.7 \\
\hline Jan 2007 to Dec 2009 & 50.7 & 48.6 & 40.4 \\
\hline Jan 2006 to Dec 2008 & 25.3 & 16.3 & 16.6 \\
\hline Jan 2005 to Dec 2007 & 189.7 & 174.4 & 174.5 \\
\hline \multicolumn{4}{|l|}{5 Years } \\
\hline Jan 2013 to Dec 2017 & 32.0 & 31.3 & 47.2 \\
\hline Jan 2012 to Dec 2016 & 30.5 & 30.3 & 38.6 \\
\hline Jan 2011 to Dec 2015 & 19.0 & 18.8 & 24.2 \\
\hline Jan 2010 to Dec 2014 & 81.7 & 84.2 & 106.2 \\
\hline Jan 2009 to Dec 2013 & 192.0 & 202.8 & 215.3 \\
\hline Jan 2008 to Dec 2012 & 43.8 & 50.2 & 57.2 \\
\hline Jan 2007 to Dec 2011 & 115.1 & 115.0 & 111.7 \\
\hline Jan 2006 to Dec 2010 & 240.9 & 233.6 & 218.2 \\
\hline Jan 2005 to Dec 2009 & 235.4 & 206.4 & 153.4 \\
\hline Jan 2004 to Dec 2008 & 146.3 & 116.9 & 95.9 \\
\hline Jan 2003 to Dec 2007 & 588.6 & 529.4 & 546.2 \\
\hline
\end{tabular}


The skewness of performance is also uncertain as sometimes the mean is higher than the median, but in another year it is the contrary. For example, for the year 2013, the mean of fund performance $(-2.8 \%)$ is higher than the median $(-4.4 \%)$. However, it is contrary to the year 2014. The median was $27.4 \%$ and the mean was $25.8 \%$.

Comparing the performance of equity funds to that of the Jakarta Composite Index (JKSE), we find vague results. The JKSE return in 2017 was $20 \%$, but the median and mean the return of equity funds was only $12.7 \%$ and $12.1 \%$ respectively. The prevailing regulation could be the main cause of this so that equity funds cannot fully invest in stocks. It means that in the bullish equity market, the equity fund cannot fully capitalize on it. In the regulation, twenty percent of assets under management could be allocated in either cash or money market instruments.

Contrary to performance in 2017, the median and mean performance of equity funds $(27.4 \%$ and $25.8 \%$, respectively) in 2014 was better than the return of JKSE $(22.3 \%)$. The reason for this could be the number (and the proportion) of stocks held in the equity funds is different from the number and weight of the stocks in the composite index. The composite index consists of hundreds of stocks, but the number of stocks in equity funds usually ranges from 20 to 40 stocks.

In the year of the bearish market $(2008,2013$, and 2015), the composite index consistently performed better than both the median and mean return of equity funds.

\subsection{Hypothesis testing result}

We employ the Chi-square test to check the independence between the relevant periods (for example, the one year with the following one-year period) using a 5\% significance level. Below is the hypothesis test that we use:

$\mathrm{H}_{1}$ : There is the persistence of equity fund performance.

The contingency table presented in Table 3 shows that the equity fund returns are not always consistent for any time frame (one year, three years, and five years). Therefore, we can conclude that there is no reliability that a longer period equity funds (five years) will produce a more persistent performance than that of shorter-term (one year and three years) as the persistence results are mixed during the relevant observed period.

Interestingly, persistence existed in the one-year time frame (the year 2010, the year 2011, and year 2012). However, in the three-year time frame (beginning 2010 to ending 2012 compared to the previous three-years period), persistence did not exist. The different results happened in the other period. The one-year return from 2014, 2015, 2016, to 2017 did not show persistence. Conversely, the three-year time frame showed persistence in the relevant period (January 2014 to December 2016 and January 2015 to December 2017).

For the consistency of the five-year return, only the period of January 2008 to December 2012 when compared to January 2003 to December 2007 shows consistency.
Table 3. The summary of results (source: Infovesta and Yahoo Finance, processed by the authors)

\begin{tabular}{|c|c|c|c|c|}
\hline $\begin{array}{c}\text { Table } \\
\text { Number }\end{array}$ & Period & $\begin{array}{l}\text { Pearson } \\
\text { Chi Sq. }\end{array}$ & p-value & $\begin{array}{l}\text { Persis- } \\
\text { tent? }\end{array}$ \\
\hline & 1 Year & & & \\
\hline Table 4 & Jan to Dec 2017 & 0.890 & 0.641 & No \\
\hline Table 5 & Jan to Dec 2016 & 3.705 & 0.157 & No \\
\hline Table 6 & Jan to Dec 2015 & 0.738 & 0.691 & No \\
\hline Table 7 & Jan to Dec 2014 & 1.272 & 0.529 & No \\
\hline Table 8 & Jan to Dec 2013 & 2.321 & 0.313 & No \\
\hline Table 9 & Jan to Dec 2012 & 7.133 & $0.028^{\star *}$ & Yes \\
\hline Table 10 & Jan to Dec 2011 & 8.111 & $0.017^{\star *}$ & Yes \\
\hline Table 11 & Jan to Dec 2010 & 18.743 & $0.000^{* * *}$ & Yes \\
\hline Table 12 & Jan to Dec 2009 & 3.286 & 0.193 & No \\
\hline \multirow[t]{2}{*}{ Table 13} & Jan to Dec 2008 & 4.512 & 0.105 & No \\
\hline & 3 Years & & & \\
\hline Table 14 & Jan 2015 to Dec 2017 & 7.244 & $0.027^{\star *}$ & Yes \\
\hline Table 15 & Jan 2014 to Dec 2016 & 6.403 & $0.041^{\star *}$ & Yes \\
\hline Table 16 & Jan 2013 to Dec 2015 & 1.135 & 0.567 & No \\
\hline Table 17 & Jan 2012 to Dec 2014 & 7.817 & $0.002^{\star * *}$ & Yes \\
\hline Table 18 & Jan 2011 to Dec 2013 & 6.177 & $0.046^{\star *}$ & Yes \\
\hline Table 19 & Jan 2010 to Dec 2012 & 2.461 & 0.292 & No \\
\hline Table 20 & Jan 2009 to Dec 2011 & 5.810 & $0.055^{\star}$ & No \\
\hline \multirow[t]{2}{*}{ Table 21} & Jan 2008 to Dec 2010 & 11.111 & $0.004^{* * *}$ & Yes \\
\hline & 5 Years & & & \\
\hline Table 22 & Jan 2013 to Dec 2017 & 0.381 & 0.827 & No \\
\hline Table 23 & Jan 2012 to Dec 2016 & 1.467 & 0.480 & No \\
\hline Table 24 & Jan 2011 to Dec 2015 & 2.667 & 0.264 & No \\
\hline Table 25 & Jan 2010 to Dec 2014 & 1.613 & 0.446 & No \\
\hline Table 26 & Jan 2009 to Dec 2013 & 5.810 & $0.055^{\star}$ & No \\
\hline Table 27 & Jan 2008 to Dec 2012 & 10.422 & $0.005^{\star * *}$ & Yes \\
\hline
\end{tabular}

Note: ${ }^{* *}$ significant at $1 \%$ level of significance; ${ }^{* \star}$ significant at $5 \%$ level of significance; ${ }^{\star}$ significant at $10 \%$ level of significance.

However, the one-year period and three-year period in the relevant period show mixed results for consistency.

If we use a $10 \%$ significance level, we can see that the number of persistent equity funds will be larger. For example, the three-year time frame (2009 to 2011) and the five-year time frame (2009 to 2013) will change from not persistent to persistent. The result summary of the Chisquare tests shown in Table 3.

Table 4 to Table 27 shows the details of the data grouped in the relevant period. Based on Table 4 we can see that from 182 mutual funds in 2016, 91 mutual funds are the winners, 91 mutual funds are the losers. In the following period (2017), from 91 winning mutual funds, 47 mutual funds still become the winners, while 42 mutual funds changed to a loser, and 2 mutual funds are defunct. From 91 loser mutual funds, 41 mutual funds upgraded 
its performances and become the winner, and 47 mutual funds still become a loser, while 3 mutual funds are defunct. About $51.648 \%$ of the mutual funds studied have persistence, while the rests did not have persistence.

Table 4. One year persistent result for 2016 as current period (source: Infovesta and Yahoo Finance, processed by the authors)

\begin{tabular}{|l|c|c|c|}
\hline Following Period (2017) & Winner & Loser & Total \\
\hline Winner & 47 & 41 & 88 \\
\hline Loser & 42 & 47 & 89 \\
\hline Defunct & 2 & 3 & 5 \\
\hline Total & 91 & 91 & 182 \\
\hline
\end{tabular}

In Table 5 we can see that from 145 mutual funds in 2015, 73 mutual funds are the winners, 72 mutual funds are the losers. In the following period (2016), from 73 winning mutual funds, 33 mutual funds still become the winners, while 39 mutual funds changed to a loser, and 1 mutual fund is defunct. From 72 loser mutual funds, 36 mutual funds upgraded its performances and become the winner, while 31 mutual funds still become a loser, and 5 mutual funds are defunct. About $44.137 \%$ of the mutual funds studied have persistence, while the rests did not have persistence.

Table 5. One year persistent result for 2015 as current period (source: Infovesta and Yahoo Finance, processed by the authors)

\begin{tabular}{|l|c|c|c|}
\hline Following Period (2016) & Winner & Loser & Total \\
\hline Winner & 33 & 36 & 69 \\
\hline Loser & 39 & 31 & 70 \\
\hline Defunct & 1 & 5 & 6 \\
\hline Total & 73 & 72 & 145 \\
\hline
\end{tabular}

In Table 6 we can see that from 124 mutual funds in 2014, 62 mutual funds are the winners, 62 mutual funds are the losers. In the following period (2015), from 62 winning mutual funds, 29 mutual funds still become the winners, while 31 mutual funds changed to a loser, and 2 mutual funds are defunct. From 62 loser mutual funds, 27 mutual funds upgraded its performances and become the winner, while 31 mutual funds still become a loser, and 4 mutual funds are defunct. About $48.387 \%$ of the mutual funds studied have persistence, while the rests did not have persistence.

Table 6. One year persistent result for 2014 as current period (source: Infovesta and Yahoo Finance, processed by the authors)

\begin{tabular}{|l|c|c|c|}
\hline Following Period (2015) & Winner & Loser & Total \\
\hline Winner & 29 & 27 & 56 \\
\hline Loser & 31 & 31 & 62 \\
\hline Defunct & 2 & 4 & 6 \\
\hline Total & 62 & 62 & 124 \\
\hline
\end{tabular}

In Table 7 we can see that from 95 mutual funds in 2013, 48 mutual funds are the winners, 47 mutual funds are the losers. In the following period (2014), from 48 winning mutual funds, 23 mutual funds still become the winners, while 22 mutual funds changed to a loser, and 3 mutual funds are defunct. From 47 loser mutual funds, 21 mutual funds upgraded its performances and become the winner, while 25 mutual funds still become a loser, and 1 mutual fund is defunct. About $50.526 \%$ of the mutual funds studied have persistence, while the rests did not have persistence.

Table 7. One year persistent result for 2013 as current period (source: Infovesta and Yahoo Finance, processed by the authors)

\begin{tabular}{|l|c|c|c|}
\hline Following Period (2014) & Winner & Loser & Total \\
\hline Winner & 23 & 21 & 44 \\
\hline Loser & 22 & 25 & 47 \\
\hline Defunct & 3 & 1 & 4 \\
\hline Total & 48 & 47 & 95 \\
\hline
\end{tabular}

In Table 8 we can see that from 77 mutual funds in 2012, 39 mutual funds are the winners, 38 mutual funds are the losers. In the following period (2013), from 39 winning mutual funds, 16 mutual funds still become the winners, while 22 mutual funds changed to a loser, and a mutual fund is defunct. From 38 loser mutual funds, 21 mutual funds upgraded its performances and become the winner, while 15 mutual funds still become a loser, and 2 mutual funds are defunct. About $40.259 \%$ of the mutual funds studied have persistence, while the rests did not have persistence.

Table 8. One year persistent result for 2012 as current period (source: Infovesta and Yahoo Finance, processed by the authors)

\begin{tabular}{|l|c|c|c|}
\hline Following Period (2013) & Winner & Loser & Total \\
\hline Winner & 16 & 21 & 37 \\
\hline Loser & 22 & 15 & 37 \\
\hline Defunct & 1 & 2 & 3 \\
\hline Total & 39 & 38 & 77 \\
\hline
\end{tabular}

In Table 9 we can see that from 65 mutual funds in 2011, 33 mutual funds are the winners, 32 mutual funds are the losers. In the following period (2012), from 33 winning mutual funds, 20 mutual funds still become the winners, while 13 mutual funds changed to a loser, and none mutual fund is defunct. From 32 loser mutual funds, 11 mutual funds upgraded its performances and become the winner, while 17 mutual funds still become a loser, and 4 mutual funds are defunct. About $59.923 \%$ of the mutual funds studied have persistence, while the rests did not have persistence.

In Table 10 we can see that from 63 mutual funds in 2010, 32 mutual funds are the winners, 31 mutual funds 
Table 9. One year persistent result for 2011 as current period (source: Infovesta and Yahoo Finance, processed by the authors)

\begin{tabular}{|l|c|c|c|}
\hline Following Period (2012) & Winner & Loser & Total \\
\hline Winner & 20 & 11 & 31 \\
\hline Loser & 13 & 17 & 30 \\
\hline Defunct & - & 4 & 4 \\
\hline Total & 33 & 32 & 65 \\
\hline
\end{tabular}

are the losers. In the following period (2011), from 32 winning mutual funds, 20 mutual funds still become the winners, while 11 mutual funds changed to a loser, and 1 mutual fund is defunct. From 31 loser mutual funds, 9 mutual funds upgraded its performances and become the winner, while 17 mutual funds still become a loser, and 5 mutual funds are defunct. About $58.730 \%$ of the mutual funds studied have persistence, while the rests did not have persistence.

Table 10. One year persistent result for 2010 as current period (source: Infovesta and Yahoo Finance, processed by the authors)

\begin{tabular}{|l|c|c|c|}
\hline Following Period (2011) & Winner & Loser & Total \\
\hline Winner & 20 & 9 & 29 \\
\hline Loser & 11 & 17 & 28 \\
\hline Defunct & 1 & 5 & 6 \\
\hline Total & 32 & 31 & 63 \\
\hline
\end{tabular}

In Table 11 we can see that from 68 mutual funds in 2009, 34 mutual funds are the winners, 34 mutual funds are the losers. In the following period (2010), from 34 winning mutual funds, 23 mutual funds still become the winners, while 10 mutual funds changed to a loser, and 1 mutual fund is defunct. From 34 loser mutual funds, 6 mutual funds upgraded its performances and become the winner, while 20 mutual funds still become a loser, and 8 mutual funds are defunct. About $63.235 \%$ of the mutual funds studied have persistence, while the rests did not have persistence.

Table 11. One year persistent result for 2009 as current period (source: Infovesta and Yahoo Finance, processed by the authors)

\begin{tabular}{|l|c|c|c|}
\hline Following Period (2010) & Winner & Loser & Total \\
\hline Winner & 23 & 6 & 29 \\
\hline Loser & 10 & 20 & 30 \\
\hline Defunct & 1 & 8 & 9 \\
\hline Total & 34 & 34 & 68 \\
\hline
\end{tabular}

In Table 12 we can see that from 54 mutual funds in 2008, 27 mutual funds are the winners, 27 mutual funds are the losers. In the following period (2009), from 27 winning mutual funds, 17 mutual funds still become the winners, while 10 mutual funds changed to a loser, and
Table 12. One year persistent result for 2008 as current period (source: Infovesta and Yahoo Finance, processed by the authors)

\begin{tabular}{|l|c|c|c|}
\hline Following Period (2009) & Winner & Loser & Total \\
\hline Winner & 17 & 11 & 28 \\
\hline Loser & 10 & 15 & 25 \\
\hline Defunct & 0 & 1 & 1 \\
\hline Total & 27 & 27 & 54 \\
\hline
\end{tabular}

none mutual fund is defunct. From 27 loser mutual funds, 11 mutual funds upgraded its performances and become the winner, while 15 mutual funds still become a loser, and 1 mutual fund is defunct. About $59.259 \%$ of the mutual funds studied have persistence, while the rests did not have persistence.

Table 13. One year persistent result for 2007 as current period (source: Infovesta and Yahoo Finance, processed by the authors)

\begin{tabular}{|l|c|c|c|}
\hline Following Period (2008) & Winner & Loser & Total \\
\hline Winner & 11 & 6 & 17 \\
\hline Loser & 7 & 8 & 15 \\
\hline Defunct & - & 3 & 3 \\
\hline Total & 18 & 17 & 35 \\
\hline
\end{tabular}

In Table 13 we can see that from 35 mutual funds in 2007, 18 mutual funds are the winners, 17 mutual funds are the losers. In the following period (2008), from 18 winning mutual funds, 11 mutual funds still become the winners, while 7 mutual funds changed to a loser, and none mutual fund is defunct. From 17 loser mutual funds, 6 mutual funds upgraded its performances and become the winner, while 8 mutual funds still become a loser, and 3 mutual funds are defunct. About $54.285 \%$ of the mutual funds studied have persistence, while the rests did not have persistence.

Table 14. Three years persistent result for beginning of 2012end of 2014 as current period (source: Infovesta and Yahoo Finance, processed by the authors)

\begin{tabular}{|l|c|c|c|}
\hline $\begin{array}{c}\text { Following Period } \\
\text { (Beg 2015-End 2017) }\end{array}$ & Winner & Loser & Total \\
\hline Winner & 23 & 16 & 39 \\
\hline Loser & 13 & 13 & 26 \\
\hline Defunct & - & 6 & 6 \\
\hline Total & 36 & 35 & 71 \\
\hline
\end{tabular}

In Table 14 we can see that from 71 mutual funds in 2012-2014, 36 mutual funds are the winners, 35 mutual funds are the losers. In the following period (2015-2017), from 36 winning mutual funds, 23 mutual funds still become the winners, while 13 mutual funds changed to a los$\mathrm{er}$, and none mutual fund is defunct. From 35 loser mutual funds, 16 mutual funds upgraded its performances and 
become the winner, while 13 mutual funds still become a loser, and 6 mutual funds are defunct. About 50.704\% of the mutual funds studied have persistence, while the rests did not have persistence.

Table 15. Three years persistent result for beginning of 2011end of 2013 as current period (source: Infovesta and Yahoo Finance, processed by the authors)

\begin{tabular}{|l|c|c|c|}
\hline $\begin{array}{c}\text { Following Period } \\
\text { (Beg 2014-End 2016) }\end{array}$ & Winner & Loser & Total \\
\hline Winner & 15 & 18 & 33 \\
\hline Loser & 15 & 8 & 23 \\
\hline Defunct & - & 4 & 4 \\
\hline Total & 30 & 30 & 60 \\
\hline
\end{tabular}

In Table 15 we can see that from 60 mutual funds in 2011-2013, 30 mutual funds are the winners, 30 mutual funds are the losers. In the following period (2014-2016), from 30 winning mutual funds, 15 mutual funds still become the winners, while 15 mutual funds changed to a loser, and none mutual fund is defunct. From 30 loser mutual funds, 18 mutual funds upgraded its performances and become the winner, while 8 mutual funds still become a loser, and 4 mutual funds are defunct. About $38.333 \%$ of the mutual funds studied have persistence, while the rests did not have persistence.

Table 16. Three years persistent result for the beginning of 2010-end of 2012 as current period (source: Infovesta and Yahoo Finance, processed by the authors)

\begin{tabular}{|l|c|c|c|}
\hline $\begin{array}{c}\text { Following Period } \\
\text { (Beg 2013-End 2015) }\end{array}$ & Winner & Loser & Total \\
\hline Winner & 14 & 10 & 24 \\
\hline Loser & 12 & 14 & 26 \\
\hline Defunct & 1 & 2 & 3 \\
\hline Total & 27 & 26 & 53 \\
\hline
\end{tabular}

In Table 16 we can see that from 53 mutual funds in 2010-2012, 27 mutual funds are the winners, 26 mutual funds are the losers. In the following period (2013-2015), from 27 winning mutual funds, 14 mutual funds still become the winners, while 12 mutual funds changed to a loser, and 1 mutual fund is defunct. From 26 loser mutual funds, 10 mutual funds upgraded its performances and become the winner, while 14 mutual funds still become a loser, and 2 mutual funds are defunct. About $52.830 \%$ of the mutual funds studied have persistence, while the rests did not have persistence.

In Table 17 we can see that from 53 mutual funds in 2009-2011, 27 mutual funds are the winners, 26 mutual funds are the losers. In the following period (2012-2014), from 27 winning mutual funds, 16 mutual funds still become the winners, while 11 mutual funds changed to a loser, and none mutual fund is defunct. From 26 loser mutual funds, 8 mutual funds upgraded its performances and become the winner, while 13 mutual funds still become a
Table 17. Three years persistent result for the beginning of 2009-end of 2011 as current period (source: Infovesta and Yahoo Finance, processed by the authors)

\begin{tabular}{|l|c|c|c|}
\hline \multicolumn{1}{|c|}{$\begin{array}{c}\text { Following Period (Beg } \\
\text { 2012-End 2014) }\end{array}$} & Winner & Loser & Total \\
\hline Winner & 16 & 8 & 24 \\
\hline Loser & 11 & 13 & 24 \\
\hline Defunct & - & 5 & 5 \\
\hline Total & 27 & 26 & 53 \\
\hline
\end{tabular}

loser, and 5 mutual funds are defunct. About $54.716 \%$ of the mutual funds studied have persistence, while the rests did not have persistence.

Table 18. Three years persistent result for the beginning of 2008-end of 2010 as current period (source: Infovesta and Yahoo Finance, processed by the authors)

\begin{tabular}{|l|c|c|c|}
\hline $\begin{array}{c}\text { Following Period } \\
\text { (Beg 2011-End 2013) }\end{array}$ & Winner & Loser & Total \\
\hline Winner & 9 & 8 & 17 \\
\hline Loser & 14 & 8 & 22 \\
\hline Defunct & 1 & 7 & 8 \\
\hline Total & 24 & 23 & 47 \\
\hline
\end{tabular}

In Table 18 we can see that from 47 mutual funds in 2008-2010, 24 mutual funds are the winners, 23 mutual funds are the losers. In the following period (2011-2013), from 24 winning mutual funds, 9 mutual funds still become the winners, while 14 mutual funds changed to a loser, and 1 mutual fund is defunct. From 23 loser mutual funds, 8 mutual funds upgraded its performances and become the winner, while 8 mutual funds still become a loser, and 7 mutual funds are defunct. About $36.170 \%$ of the mutual funds studied have persistence, while the rests did not have persistence.

Table 19. Three years persistent result for the beginning of 2007-end of 2009 as current period (source: Infovesta and Yahoo Finance, processed by the authors)

\begin{tabular}{|l|c|c|c|}
\hline $\begin{array}{c}\text { Following Period } \\
(\text { Beg 2010-End 2012) }\end{array}$ & Winner & Loser & Total \\
\hline Winner & 9 & 6 & 15 \\
\hline Loser & 6 & 5 & 11 \\
\hline Defunct & 1 & 4 & 5 \\
\hline Total & 16 & 15 & 31 \\
\hline
\end{tabular}

In Table 19 we can see that from 31 mutual funds in 2007-2009, 16 mutual funds are the winners, 15 mutual funds are the losers. In the following period (2010-2012), from 16 winning mutual funds, 9 mutual funds still become the winners, while 6 mutual funds changed to a loser, and 1 mutual fund is defunct. From 15 loser mutual funds, 6 mutual funds upgraded its performances and become the winner, while 5 mutual funds still become a 
loser, and 4 mutual funds are defunct. About $45.161 \%$ of the mutual funds studied have persistence, while the rests did not have persistence.

Table 20. Three years persistent result for the beginning of 2006-end of 2008 as current period (source: Infovesta and Yahoo Finance, processed by the authors)

\begin{tabular}{|l|c|c|c|}
\hline $\begin{array}{c}\text { Following Period } \\
\text { (Beg 2009-End 2011) }\end{array}$ & Winner & Loser & Total \\
\hline Winner & 10 & 5 & 15 \\
\hline Loser & 3 & 4 & 7 \\
\hline Defunct & - & 4 & 4 \\
\hline Total & 13 & 13 & 26 \\
\hline
\end{tabular}

In Table 20 we can see that from 26 mutual funds in 2006-2008, 13 mutual funds are the winners, 13 mutual funds are the losers. In the following period (2009-2011), from 13 winning mutual funds, 10 mutual funds still become the winners, while 3 mutual funds changed to a loser, and none mutual fund is defunct. From 13 loser mutual funds, 5 mutual funds upgraded its performances and become the winner, while 4 mutual funds still become a loser, and 4 mutual funds are defunct. About $53.846 \%$ of the mutual funds studied have persistence, while the rests did not have persistence.

In Table 21 we can see that from 21 mutual funds in 2005-2004, 11 mutual funds are the winners, 10 mutual funds are the losers. In the following period (2008-2010), from 11 winning mutual funds, 10 mutual funds still become the winners, while 1 mutual fund changed to a loser, and none mutual fund is defunct. From 10 loser mutual funds, 2 mutual funds upgraded its performances and become the winner, while 4 mutual funds still become a loser, and 4 mutual funds are defunct. About $66.667 \%$ of the mutual funds studied have persistence, while the rests did not have persistence.

Table 21. Three years persistent result for the beginning of 2005-end of 2007 as current period (source: Infovesta and Yahoo Finance, processed by the authors)

\begin{tabular}{|l|c|c|c|}
\hline $\begin{array}{c}\text { Following Period } \\
\text { (Beg 2008-End 2010) }\end{array}$ & Winner & Loser & Total \\
\hline Winner & 10 & 2 & 12 \\
\hline Loser & 1 & 4 & 5 \\
\hline Defunct & - & 4 & 4 \\
\hline Total & 11 & 10 & 21 \\
\hline
\end{tabular}

Table 22. Five years persistent result for beginning of 2008end of 2012 as current period (source: Infovesta and Yahoo Finance, processed by the authors)

\begin{tabular}{|l|c|c|c|}
\hline $\begin{array}{c}\text { Following Period } \\
\text { (Beg 2013-End 2017) }\end{array}$ & Winner & Loser & Total \\
\hline Winner & 11 & 10 & 21 \\
\hline Loser & 8 & 8 & 16 \\
\hline Defunct & 1 & 2 & 3 \\
\hline Total & 20 & 20 & 40 \\
\hline
\end{tabular}

In Table 22 we can see that from 40 mutual funds in 2008-2012, 20 mutual funds are the winners, 20 mutual funds are the losers. In the following period (2013-2017), from 20 winning mutual funds, 11 mutual funds still become the winners, while 8 mutual funds changed to a loser, and 1 mutual fund is defunct. From 20 loser mutual funds, 10 mutual funds upgraded its performances and become the winner, while 8 mutual funds still become a loser, and 2 mutual funds are defunct. About $47.5 \%$ of the mutual funds studied have persistence, while the rests did not have persistence.

Table 23. Five years persistent result for the beginning of 2007end of 2011 as current period (source: Infovesta and Yahoo Finance, processed by the authors)

\begin{tabular}{|l|c|c|c|}
\hline $\begin{array}{c}\text { Following Period } \\
\text { (Beg 2012-End 2016) }\end{array}$ & Winner & Loser & Total \\
\hline Winner & 8 & 7 & 15 \\
\hline Loser & 4 & 6 & 10 \\
\hline Defunct & 1 & - & 1 \\
\hline Total & 13 & 13 & 26 \\
\hline
\end{tabular}

In Table 23 we can see that from 26 mutual funds in 2007-2011, 13 mutual funds are the winners, 13 mutual funds are the losers. In the following period (2012-2016), from 13 winning mutual funds, 8 mutual funds still become the winners, while 4 mutual funds changed to a loser, and 1 mutual fund is defunct. From 13 loser mutual funds, 7 mutual funds upgraded its performances and become the winner, while 6 mutual funds still become a loser, and none mutual fund is defunct. About $53.846 \%$ of the mutual funds studied have persistence, while the rests did not have persistence.

Table 24. Five years persistent result for the beginning of 2006end of 2010 as current period (source: Infovesta and Yahoo Finance, processed by the authors)

\begin{tabular}{|l|c|c|c|}
\hline $\begin{array}{c}\text { Following Period } \\
\text { (Beg 2011-End 2015) }\end{array}$ & Winner & Loser & Total \\
\hline Winner & 8 & 4 & 12 \\
\hline Loser & 3 & 6 & 9 \\
\hline Defunct & 1 & 2 & 3 \\
\hline Total & 12 & 12 & 24 \\
\hline
\end{tabular}

In Table 24 we can see that from 24 mutual funds in 2006-2010, 12 mutual funds are the winners, 12 mutual funds are the losers. In the following period (2011-2015), from 12 winning mutual funds, 8 mutual funds still become the winners, while 3 mutual funds changed to a loser, and 1 mutual fund is defunct. From 12 loser mutual funds, 4 mutual funds upgraded its performances and become the winner, while 6 mutual funds still become a loser, and 2 mutual funds are defunct. About $58.333 \%$ of the mutual funds studied have persistence, while the rests did not have persistence. 
Table 25. Five years persistent result for the beginning of 2005end of 2009 as current period (source: Infovesta and Yahoo Finance, processed by the authors)

\begin{tabular}{|l|c|c|c|}
\hline $\begin{array}{c}\text { Following Period } \\
\text { (Beg 2010-End 2014) }\end{array}$ & Winner & Loser & Total \\
\hline Winner & 6 & 3 & 9 \\
\hline Loser & 2 & 4 & 6 \\
\hline Defunct & 1 & 1 & 2 \\
\hline Total & 9 & 8 & 17 \\
\hline
\end{tabular}

In Table 25 we can see that from 17 mutual funds in 2005-2009, 9 mutual funds are the winners, 8 mutual funds are the losers. In the following period (2010-2014), from 9 winning mutual funds, 6 mutual funds still become the winners, while 2 mutual funds changed to a loser, and 1 mutual fund is defunct. From 8 loser mutual funds, 3 mutual funds upgraded its performances and become the winner, while 4 mutual funds still become a loser, and 1 mutual fund is defunct. About $58.823 \%$ of the mutual funds studied have persistence, while the rests did not have persistence.

Table 26. Five years persistent result for the beginning of 2004end of 2008 as current period (source: Infovesta and Yahoo Finance, processed by the authors)

\begin{tabular}{|l|c|c|c|}
\hline $\begin{array}{c}\text { Following Period } \\
\text { (Beg 2009-End 2013) }\end{array}$ & Winner & Loser & Total \\
\hline Winner & 5 & 1 & 6 \\
\hline Loser & 3 & 4 & 7 \\
\hline Defunct & - & 3 & 3 \\
\hline Total & 8 & 8 & 16 \\
\hline
\end{tabular}

In Table 26 we can see that from 16 mutual funds in 2004-2008, 8 mutual funds are the winners, 8 mutual funds are the losers. In the following period (2009-2013), from 8 winning mutual funds, 5 mutual funds still become the winners, while 3 mutual funds changed to a loser, and none mutual fund is defunct. From 8 loser mutual funds, 1 mutual fund upgraded its performances and become the winner, while 4 mutual funds still become a loser, and 3 mutual funds are defunct. About $56.25 \%$ of the mutual funds studied have persistence, while the rests did not have persistence.

Table 27. Five years persistent result for the beginning of 2003end of 2007 as current period (source: Infovesta and Yahoo Finance, processed by the authors)

\begin{tabular}{|l|c|c|c|}
\hline $\begin{array}{c}\text { Following Period } \\
\text { (Beg 2008-End 2012) }\end{array}$ & Winner & Loser & Total \\
\hline Winner & 8 & 1 & 9 \\
\hline Loser & 1 & 3 & 4 \\
\hline Defunct & - & 4 & 4 \\
\hline Total & 9 & 8 & 17 \\
\hline
\end{tabular}

In Table 27 we can see that from 17 mutual funds in 2003-2007, 9 mutual funds are the winners, 8 mutual funds are the losers. In the following period (2008-2012), from 9 winning mutual funds, 8 mutual funds still become the winners, while 1 mutual fund changed to a loser, and none mutual fund is defunct. From 8 loser mutual funds, 1 mutual fund upgraded its performances and become the winner, while 3 mutual funds still become a loser, and 4 mutual funds are defunct. About $64.705 \%$ of the mutual funds studied have persistence, while the rests did not have persistence.

Table 4 to Table 27 shows that the performance of the mutual fund tends to move randomly. Past performance cannot become a benchmark for future performance. As shown in Table 3 which summarized these tables, only one persistent performance occurred for a long time frame which is a five-year time frame, three persistent performances occurred for a medium time frame which is the three-year time frame and five persistent performances occurred for short time frame which is the one-year time frame. Overall, the persistence level of the five-year time frame is $56.576 \%$; the three-year time frame is $50.053 \%$; the one-year time frame is $53.039 \%$.

This finding is consistent with Filip (2018), which found many variations regarding the performance of mutual funds. The findings of this study are neither supporting nor opposing the efficient market hypothesis. This paper is consistent with Fan and Addams (2012) saying that the performance of the mutual fund is more like a random walk, not a persistent trend. Also, consistent with the finding of Hanke et al. (2018) that equity funds do not have performance persistence. Moreover, this finding also supports Deb (2019), Kiymaz and Simsek (2017) and Christiansen et al. (2020) found that the variation in performance persistence tends to be induced by varying the time frame is robust to weighting schemes and sample periods.

\section{Conclusions}

The purpose of the paper was to observe the performance persistence of the equity fund population (not only a sample) in various and long enough time frames (one, three, and five years) of the most recent equity funds (from 2007 to 2017). Taking the abovementioned observations into consideration, it should be noted that hypothesis $\mathrm{H}_{1}$ regarding the persistence of equity fund performance should be rejected. In specific, there is no certainty that the winner will become the winner in the observed period. Investors usually search the historical return information for any funds that they intend to invest in. However, based on this research, they should be conscious that the positive past returns will not be always repeated in the next period. This finding could also prove that the suggestion of the OJK to state "the past returns will not represent the future returns" in the mutual fund prospectus is make sense and worthy. 
This paper makes several contributions to the finance literature. Most importantly, a long-term historical performance cannot be considered as a more reliable measurement than the short-term one. There is no evidence that the performance of a longer time frame (three years or five years) will be more persistent than that of a shorter time frame. Both the long-time frame and short-time frame show mixed results of persistence for various periods.

Several limitations come along with this study, in this study, our population still lacks certain attributes/issues such as fund size and growth versus value funds. Also, in this study, equity funds categorized as both sharia and conventional equity funds are not analyzed. In Indonesia, especially during the past three years, the sharia mutual fund was being flourished. Hence, this would be interesting if, in future research, equity funds separated to be non-sharia equity funds and sharia equity funds, and the results of the future study can be used as a reference for Muslim investors, the majority of the Indonesian population.

\section{Funding}

This research received no specific grant from any funding agency in the public, commercial, or not-for-profit sectors.

\section{Author contributions}

Budi Frensidy and Reynardo Nainggolan conceived the study and were responsible for the design and development of the data analysis. Budi Frensidy and Reynardo Nainggolan were responsible for data collection and analysis. Budi Frensidy and Reynardo Nainggolan and Robiyanto Robiyanto were responsible for data interpretation. Budi Frensidy and Reynardo Nainggolan and Robiyanto Robiyanto wrote the first draft of the article.

\section{Disclosure statement}

The authors declare that there is no conflict of interest.

\section{References}

Angelidis, T., Giamouridis, D., \& Tessaromatis, N. (2013). Revisiting mutual fund performance evaluation. Journal of Banking \& Finance, 37(5), 1759-1776.

https://doi.org/10.1016/j.jbankfin.2013.01.006

Antonakakis, N., Chang, T., Cunado, J., \& Gupta, R. (2018). The relationship between commodity markets and commodity mutual funds: A wavelet-based analysis. Finance Research Letters, 24, 1-9. https://doi.org/10.1016/j.frl.2017.03.005

Babalos, V., Mamatzakis, E. C., \& Matousek, R. (2015). The performance of US equity mutual funds. Journal of Banking \& Finance, 52, 217-229.

https://doi.org/10.1016/j.jbankfin.2014.12.008

Christiansen, C., Grønborg, N. S., \& Nielsen, O. L. (2020). Mutual fund selection for realistically short samples. Journal of Empirical Finance, 55, 218-240.

https://doi.org/10.1016/j.jempfin.2019.12.001
Deb, S. G. (2019). Persistence in performance of actively managed equity mutual funds: New Indian evidence. IIMB Management Review, 31(2), 145-156.

https://doi.org/10.1016/j.iimb.2019.03.014

Devaney, M., Morillon, T., \& Weber, W. (2016). Mutual fund efficiency and tradeoffs in the production of risk and return. Managerial Finance, 42(3), 225-243.

https://doi.org/10.1108/MF-05-2015-0142

Dumitrescu, A., \& Gil-Bazo, J. (2018). Market frictions, investor sophistication, and persistence in mutual fund performance. Journal of Financial Markets, 40, 40-59. https://doi.org/10.1016/j.finmar.2018.01.001

Fama, E. F., \& French, K. R. (2010). Luck versus skill in the crosssection of mutual fund returns. Journal of Finance, 65(5), 1915-1947. https://doi.org/10.1111/j.1540-6261.2010.01598.x

Fan, Y., \& Addams, H. L. (2012). United States-based international mutual funds: performance and persistence. Financial Services Review, 21(1), 51-61.

Filip, D. (2018). The impact of fund attributes on performance: Empirical evidence for Polish equity funds. Zbornik radova Ekonomskog fakulteta u Rijeci, 36(2), 465-488.

Fortin, R., \& Michelson, S. (2010). Mutual fund performance persistence: still true? Academy of Accounting and Financial Studies Journal, 14(4), 29-41.

Frensidy, B. (2016). The performance of undiversified portfolio In Indonesia stock exchange. Journal of Applied Business Research, 32(4), 1041-1048.

https://doi.org/10.19030/jabr.v32i4.9720

Frensidy, B., Utama, S., \& Prijadi, R. (2017). An analysis of diversification practice of domestic individual investors in the Indonesia stock exchange. International Journal of Applied Business and Economic Research, 15(19), 137-148.

Glode, V. (2011). Why mutual funds "underperform". Journal of Financial Economics, 99(3), 546-559.

https://doi.org/10.1016/j.jfineco.2010.10.008

Grau-Carles, P., Doncel, L. M., \& Sainz, J. (2018). Stability in mutual fund performance rankings: A new proposal. International Review of Economics \& Finance, 61, 337-346.

https://doi.org/10.1016/j.iref.2018.01.018

Hanke, B., Keswani, A., Quigley, G., \& Zagonov, M. (2018). Survivorship bias and comparability of UK open-ended fund databases. Economics Letters, 172, 110-114.

https://doi.org/10.1016/j.econlet.2018.08.027

Ibbotson, R. G., \& Kaplan, P. D. (2000). Does asset-allocation policy explain 40 percent, 90 percent, or 100 percent of performance? Financial Analyst Journal, 56, 26-33.

https://doi.org/10.2469/faj.v56.n1.2327

Jeon, H., Kang, J., \& Lee, C. (2017). Precision about manager skill, mutual fund flows, and performance persistence. The North American Journal of Economics and Finance, 40, 222237. https://doi.org/10.1016/j.najef.2017.03.002

Kiymaz, H., \& Simsek, K. D. (2017). The performance of USbased emerging market mutual funds. Journal of Capital Markets Studies, 1(1), 58-73.

https://doi.org/10.1108/JCMS-10-2017-003

Kourtis, A. (2016). The Sharpe ratio of estimated efficient portfolios. Finance Research Letters, 17, 72-78. https://doi.org/10.1016/j.frl.2016.01.009

Matallín-Sáez, J. C., Soler-Domínguez, A., \& Tortosa-Ausina, E. (2016). On the robustness of persistence in mutual fund performance. The North American Journal of Economics and Finance, 36, 192-231.

https://doi.org/10.1016/j.najef.2016.01.002 
Matallín-Sáez, J. C., Soler-Domínguez, A., Tortosa-Ausina, E., \& de Mingo-López, D. V. (2019). Ethical strategy focus and mutual fund management: Performance and persistence. Journal of Cleaner Production, 213, 618-633. https://doi.org/10.1016/j.jclepro.2018.12.130

Nguyen, A.-N., Shahid, M. S., \& Kernohan, D. (2018). Investor confidence and mutual fund performance in emerging markets. Journal of Economic Studies, 45(6), 1288-1310. https://doi.org/10.1108/JES-07-2017-0175

Pangestuti, I. R. D., Wahyudi, S., \& Robiyanto, R. (2017). Performance evaluation of equity mutual funds in Indonesia period of 2012-2014. Jurnal Keuangan dan Perbankan, 21(4), 527-542. https://doi.org/10.26905/jkdp.v21i4.1503

Rao, Z.-u.-R., Tauni, M. Z., Iqbal, A., \& Umar, M. (2017). Emerging market mutual fund performance: evidence for China. Journal of Asia Business Studies, 11(2), 167-187. https://doi.org/10.1108/JABS-10-2015-0176

Robiyanto, R., Santoso, M. A., \& Ernayani, R. (2019). Sharia mutual funds performance in Indonesia. Business: Theory and Practice, 20, 11-18. https://doi.org/10.3846/btp.2019.02

Robiyanto, R., Wahyudi, S., \& Pangestuti, I. R. D. (2017). The volatility-variability hypotheses testing and hedging effectiveness of precious metals for the Indonesian and Malaysian capital markets. Gadjah Mada International Journal of Business, 19(2), 167-192. https://doi.org/10.22146/gamaijb.26260

Rodriguez, J., \& Joseph McCarthy, P. (2015). Are micro-cap mutual funds indeed riskier? Review of Accounting and Finance, 14(4), 352-362. https://doi.org/10.1108/RAF-03-2015-0045

Shive, S., \& Yun, H. (2013). Are mutual funds sitting ducks? Journal of Financial Economics, 107(1), 220-237. https://doi.org/10.1016/j.jfineco.2012.08.012
Treynor, J. L. (2012). Can mutual funds outguess the market?: A report on the performance of 57 funds and their sensitivity to market fluctuations. In J. L. Treynor (Ed.), Treynor on Institutional Investing (pp. 88-96). John Wiley \& Sons, Inc. https://doi.org/10.1002/9781119196679

Turtle, H. J., \& Zhang, C. (2012). Time-varying performance of international mutual funds. Journal of Empirical Finance, 19(3), 334-348. https://doi.org/10.1016/j.jempfin.2012.03.003

Vidal-García, J. (2013). The persistence of European mutual fund performance. Research in International Business and Finance, 28, 45-67. https://doi.org/10.1016/j.ribaf.2012.09.004

Vidal-García, J., Vidal, M., Boubaker, S., \& Uddin, G. S. (2016). The short-term persistence of international mutual fund performance. Economic Modelling, 52, 926-938. https://doi.org/10.1016/j.econmod.2015.10.031

Wattanatorn, W., Padungsaksawasdi, C., Chunhachinda, P., \& Nathaphan, S. (2020). Mutual fund liquidity timing ability in the higher moment framework. Research in International Business and Finance, 51. https://doi.org/10.1016/j.ribaf.2019.101105

Widodo, W., \& Robiyanto, R. (2018). Equity mutual fund performance: the case of Indonesia. UTCC International Journal of Business and Economics (UTCC IJBE), 10(3), 19-36.

Zulkafli, A. H., Ahmad, Z., \& Muttaqin, E. E (2017). The performance of socially responsible investments in Indonesia: a study of the Sri Kehati Index (SKI). Gadjah Mada International Journal of Business, 19(1), 59-76. https://doi.org/10.22146/gamaijb.17959 